\title{
NOTAS SOBRE EL PESIMISMO ACTIVO EN LA LITERATURA ESPAÑOLA HACIA 1900. (Un fin de siglo entre la voluntad y el dolor de vivir)
}

\author{
Cecilio ALONSO \\ U.N.E.D. \\ C.A. VALENCIA
}

El gran acierto de Emilia Pardo Bazán, en marzo de 1904, al publicar su ya clásico bosquejo de la nueva generación de narradores españoles, fue el de no disimular la variedad de tendencias, residuales unas, innovadoras otras, que coexistían en aquellos momentos, ni mucho menos ceder a la tentación de menospreciar las novedades con objeto de reforzar sus propias posiciones estéticas. Doña Emilia se resistía a contemplar el movimiento literario de principios de siglo con restricciones generacionales, mostrándose comprensiva con la iconoclasia de los jóvenes y apostando por la continuidad ("la nueva generación que reniega de sus progenitores, no realizará el imposible de nacer de sí misma"), aunque no pudiera evitar -convencida de las "conquistas definitivas" del realismo-- cierto desagrado ante la fatiga, la desilusión y el pesimismo que rezumaba la joven literatura. Pero, la impresión predominante es la de su generosidad vital e inteligencia cuando, al otear el presente de los escritores nuevos, anteponía el concepto de novedad al de la simple juventud, y advertía en ellos, como base de aquélla, su propensión al neorromanticismo entre cuyas causas más inmediatas se hallaba la lectura de Schopenhauer' .

1 "Ni importan los años que cuenten los escritores de que hablaré en este estudio. Haylos muy mozos; otros, ya en la plenitud de la vida. Es lo nuevo de su literatura lo que para mí constituye su juventud, y lo reciente de su fama, que en algunos apenas alborea lo que justifica su inclusión en el catálogo. [...] Por mi parte diría que los nuevos escritores no son inferiores a los antiguos ni en talento. Acaso tienen hasta percepción más fina de las relaciones y significación de cuanto les rodea. Creyérase, sin embargo, que un genio maléfico les veda expresar y desenvolver esta percepción por modo tan 
El catálogo-canon de doña Emilia ${ }^{2}$ constituye un buen punto de partida para estudiar detenidamente hasta dónde llegan esas "transparencias" del filósofo alemán en la joven literatura española del novecientos. Tarea atractiva, que sería interesante abordar mediante una relectura sistemática de los autores mencionados. En su defecto, me limitaré aquí a algunas calas orientativas, un poco al hilo de lecturas morosas, que permitan rastrear la sombra del pesimismo generado por la hipersensibilidad de un sujeto que se aferra a la voluntad de vivir (soporte del ser, esencia del hombre y del universo) como única alternativa al nihil negativum, la nada absoluta, inconcebible por la razón, de que hablaba Schopenhauer.

Porque, a la hora de vincular con su pensamiento el pesimismo de la literatura española finisecular, fuerza es recordar que sus indicadores más notorios aparecen enmarcados en procesos activos, de modo que si la voluntad de vivir, como forma superior del conocimiento, engendra dolor, tristeza y melancolía, estos sentimientos generan gestos disconformes de carácter existencial y hasta social, expresados mediante "fugas" (interiores o viajeras) en busca del reposo espiritual ("nirvana" o "ataraxia"), desde un ámbito urbano a otro rural, en forma de "caminos de perfección", ejercicios gnósticos, que sacralizan la naturaleza y el pueblo intrahistórico - tanto en formas místicas panteístas como en figuraciones paganizantes- o agnósticos, resueltos a veces con la referencia al suicidio alegórico. En medio de todo ello, como impulso determinista, el instinto -el genio de la especie, fuente de ilusiones que desembocan en la nada - y el recurso a un arte salvador: impulso clave de la ecuación entre la voluntad de vivir - amor, ciencia, arte- y el dolor universal. Pero ni la subordinación relativa a otros valores más amplios, ni la perfecta conciencia de sí, que se adquiere suprimiendo la voluntad y reconociéndose en todo lo existente, pueden alentar otra cosa que la ilusión de un conocimiento

artístico y fuerte como debieran. Agitados por sobreexcitación nerviosa, o abatidos por una especie de indiferente cansancio... [...] [sus libros] son, en general, cortos de resuello; revelan fatiga, y proclaman a cada página lo inútil del esfuerzo y la vanidad de todo. Muéstrase esta generación imbuida de pesimismo, con ráfagas de misticismo católico a la moderna (sin fe ni prácticas), y propende a un neorromanticismo que transparenta las influencias mentales del Norte - Nietzsche, Schopenhauer, Maeterlinck - autores que aquí circulan traducidos" (Pardo Bazán, 1904, págs. 17-18).

2 Por orden de mención: José Nogales, Francisco Acebal, Martínez Ruiz, Pío Baroja, Llanas Aguilaniedo, Valle-Inclán, Mauricio López Roberts, el Marqués de Villasinda, Felipe Trigo, W. E. Retana, Luis y Agustín Millares Cubas, Alfonso Danvila, Hoyos y Vinent, Muñoz Pavón, Melchor Almagro, Victor Caralá, Blanca de los Ríos, Martínez Sierra, Heraclio Pérez Placer, Julio Pellicer, Antonio Zozaya, Eduardo Zamacois, Luis López Allué, Gomila, Sánchez Ruiz y Rancés. Se excluyen, claro es escritores como Galdós, pese a su proyección en la literatura joven, y -más sorprendentemente- otros que, como B lasco Ibáñez, no participaban, al parecer, de la debilidad congénita de sus coetáneos. Implícitamente, pues, doña Emilia distinguía entre realistas, narradores-explicadores de la realidad, por una parte, y náufragos débiles a merced de las nuevas interrogantes finiseculares, por otra. Trataremos de comprobar al final de estas notas hasta qué punto también Blasco Ibáñez se vio en algún instante, desde luego posterior a 1904, afectado por el morbo pesimista, particularmente en su repudiada novela $E l$ dolor de vivir (1953), escrita en 1907. 
destinado a desembocar siempre en la nada. "La negación, la supresión y la conversión de la voluntad significa también la negación y supresión del mundo, su espejo" (Schopenhauer [1818-1844] 1960, III, pág. 110). Así, todo camino de perfección, todo deseo de quietud, aparecen como formas de un sueño místico que el filósofo miraba "con dolorosa y profunda melancolía". El único consuelo posible es la nada como fin del inacabable dolor de vivir.

Extraer del pesimismo motivos para la acción, luchar contra la debilidad cívica (abulia disolvente, decadentismo) que estas ideas parecían propiciar a ojos krausopositivistas o regeneracionistas ${ }^{3}$, suponía una actitud "voluntarista" estimulada, desde 1900, por la pujante presencia del vitalismo nietzscheano, especialmente activo en una coyuntura histórica crítica. Pero, aparte el hecho de que no faltó quien advirtiera - Baroja, por ejemplo, siguiendo a Nordau - que el pensamiento de Nietzsche era, en buena parte, consecuencia dinámica del propio pensamiento de Schopenhauer, no se debe olvidar que éste comenzó a divulgarse entre la juventud literaria española por lo menos diez años antes que el de aquél ${ }^{4}$. El filósofo de Danzig, pese a la negatividad profunda que se atribuyó a su doctrina, incorporaba actitudes de piedad humana, solidaria con todo tipo de seres vivos, que alentaban - en la contradicción estaba su atractivo - vagas ilusiones fundidas con desesperanzas, engarzadas en intuiciones y en sensaciones que, obviamente, la poética simbolista se encargó de desarrollar. Estamos, pues, ante un pesimismo muy particular, reversible, cuya conciencia de la nada, provoca, por lo general, un frenético regreso hacia la vida. Pesimismo fecundo que neutraliza sus efectos más desoladores, del que trataremos de revisar algunas manifestaciones poco transitadas, sin otra intención que la de contribuir a perfilar los rasgos de la recepción de Schopenhauer en España a caballo de dos siglos.

3 Cf. González Serrano (1902) ya atribuía a influencia de Schopenhauer el "menosprecio de toda base objetiva" de que hacían gala los jóvenes escritores modernistas. En aquella encrucijada de generaciones, González Serrano apostaba por el racionalismo progresista para sostener un criterio capaz de contener los desórdenes del espíritu finisecular: "No es posible provocar bruscamente la aceleración del movimiento de la vida, ya que no se vive de negaciones, sin el punto de apoyo de un nuevo ideal que se nutra de afirmaciones.".

4 Las primeras ediciones que conozco de Schopenhauer en castellano fueron, por orden cronológico: Parerga y paralipomena. Aforismos sobre la sabiduría de la vida; trad. de Antonio Zozaya, 2 t., Madrid, Biblioteca Económica Filosófica, 1889.-Estudios escogidos, Madrid, La España Moderna, [h. 1893].- - El fundamento de la moral, Madrid, La España Moderna, 1896.- El Mundo como Voluntad y Representación; trad. de A. Zozaya y E. González Blanco, Madrid, La España Moderna, 1896-1902, 3 t.-Sobre la voluntad en la Naturaleza; trad. de M. de Unamuno. Madrid, Rodríguez Serra [1900] [Biblioteca de Filosofía y Sociología, 1]. - Metafísica de lo Bello y estética; trad. de Luis Jiménez y García de Luna, Madrid, Rodríguez Serra [1901] [Biblioteca de Filosofía y Sociología, 10].El amor, las mujeres y la muerte; trad. de A. López White. Valencia, Sempere [1902]. - Apuntes para la Historia de la Filosofía; trad. de Luis Jiménez y García de Luna. Madrid, Viuda de Rodríguez Serra [1903] [Biblioteca de Filosofía y Sociología, 13].- Los dolores del mundo, Barcelona, Presa, 1904 [Los pequeños grandes libros, 9]. Las primeras traducciones de Nietzsche no comenzaron a aparecer en libro hasta 1900. (Cf. Sobejano, 1967, págs. 67 y ss.). 


\section{Resistencia al pesimismo de Schopenhauer}

Sin embargo, las primeras lecturas españolas de su obra no hicieron especial hincapié en el tópico pesimista. Más bien parece que reparaban en aspectos accidentales o anecdóticos de su pensamiento.Así sucede con Giner de los Ríos ([1869], 1922, págs. 49-50) que lo mencionaba de pasada cuando aludía a la "antigua doctrina de la metempsícosis renovada la genialidad de Schopenhauer". Pocos años después ([1872] 1919 págs. 35, 42) lo incluía en la relación de tratadistas contemporáneos que explicaban la comicidad por la teoría del contraste o desproporción entre la idea y el hecho, y constataba su concepto del humor "como manifestación fundamental de lo bello en la vida moderna". En ningún caso apreciaba el tópico del pesimismo como rasgo definidor del filósofo, del que tampoco hay rastro en una referencia de Emilio Huelin (1870, págs. 678-679), documentada con extensa bibliografía, donde, tras registrar la rápida propagación de su doctrina en Alemania, hacía hincapié en su antihegelianismo, en el carácter inductivo de su método, que el criterio del comentarista consideraba próximo al "materialismo positivo", para acabar llamando la atención sobre el particular sesgo hispánico de una de "las más poderosas inteligencias" del siglo que

los españoles debían mirar con cierta predilección, porque era entusiasta de nuestra literatura, de la que tiene varias obras traducidas, y tomados pensamientos de Calderón, a quien calificó el primer genio del mundo.

No sería ocioso recordar que ya Pérez Galdós (1876, pág. 380) aludió a Schopenhauer en el cap. IX de Doña Perfecta cuando el pedante Jacintito, tras confundir panteísmo y panenteísmo, lo sume en común anatema con los krausistas y con "el moderno" Hartmann. Pero es en algunos pasajes de Fortunata y Jacinta, donde el novelista se mostró, implícitamente, más receptivo al pensamiento del filósofo como soporte de digresiones vitalistas, ajenas todavía a cualquier tipo de angustia o temblor simbolista. Véase el tópico del genio de la especie, en la exposición casi metafísica de la vida sexual, que hace Don Evaristo González Feijoo a Fortunata $\left[3^{\mathrm{a}}, \mathrm{III}, \mathrm{V}\right]$ :

El amor es la reclamación de la especie que quiere perpetuarse, y al estímulo de esta necesidad tan conservadora como el comer, los sexos se buscan y las uniones se verifican por elección fatal, superior y extraña a todos los artificios de la Sociedad. Míranse un hombre y una mujer. ¿Qué es? La exigencia de la especie que pide un nuevo ser, y este nuevo ser reclama de sus probables padres que le den vida. Todo lo demás es música; fatuidad y palabrería de los que han querido hacer una Sociedad en sus gabinetes, fuera de las bases inmortales de la Naturaleza (Pérez Galdós, 1887, III, págs, 158-159).

La permanente renovación de la universal voluntad de vivir, el árbol de la vida, asumida ahora por la propia voz del narrador, se concreta en esta breve alegoría de la fecunda muerte de Moreno Isla [ $\left.4^{\mathrm{a}}, \mathrm{II}, \mathrm{VI}\right]$ :

La vida cesó en él, a consecuencia del estallido y desbordamiento vascular, produciéndole conmoción instantánea, tan pronto iniciada como extinguida. Se 
desprendió de la humanidad, cayó del gran árbol la hoja completamente seca, sólo sostenida por fibra imperceptible. El árbol no sintió nada en sus inmensas ramas. Por aquí y por allí caían en el mismo instante hojas y más hojas inútiles; pero la mañana próxima había de alumbrar innumerables pimpollos, frescos y nuevos (Pérez Galdós, 1887, IV, págs. 157-158).

Galdós también elude el tópico pesimista al comienzo de la Jornada II de Realidad (1890, pág. 88) cuando Manolo Infante recuerda animosamente a Federico Viera que, según Schopenhauer, el autoanálisis del dolor físico contribuye a aliviarlo.

Por su parte, Clarín (1892, págs. 261-271), que lo había valorado positivamente como uno de los pensadores que más se habían acercado al ideal del filósofo artista, "a la influencia del poeta en la idea", sin prestar tampoco importancia a la cuestión del pesimismo, poco tiempo después (Cartas a Hamlet) no dudaba en combatir el decadentismo de los jôvenes fin de siglo, uno de cuyos pilares era el alemán (Anna Krause, 1955, pág. 135).

Igualmente, una de las primeras lecturas extensas de Schopenhauer en los años de la regencia, la de Antonio Zozaya" ("Epílogo" a su traducción de Parerga y paralipómena), se resistía al "pesimismo sistemático" contraponiéndole la benéfica influencia del "pesimismo artístico" propio del estado positivo: poetas y filósofos de todos los tiempos - argumentaba - se han quejado de la condición triste y miserable del hombre:

Se puede decir con justicia que el pesimismo integra todas las concepciones artísticas; $y$ ¿no diremos más bien que se confunde aquí el estado individual y momentáneo del artista, con su idea del mundo y de la vida, que se confunde la queja con la desesperación, la tristeza con el pesimismo? [...] Detrás de todas las quejas que el Arte formula; detrás de todas las imprecaciones contra el mal, se transparenta la aspiración al bien, su deseo. [...] Así como la naturaleza tiene horror al vacío, el hombre sólo desea lo que tiene realidad (Zozaya 1889, II, pág. 182).

En cambio, Schopenhauer "hombre de sombrío carácter" —según Zozayahabía fundado su sistema en un pesimismo tan radical que pocos discípulos llegaron a asimilarlo en su integridad: unos no pudieron aceptar el idealismo voluntarista de quien afirmaba "soy porque quiero ser"; otros trataron de endulzar su doctrina, y no faltaron, en fin, quienes combatieron abiertamente su dogmatismo. Zozaya se apoyaba en el pensamiento krausopositivista de Gumersindo de Azcárate (El pesimismo en su relación con la vida práctica) para reivindicar el carácter purificador y redentor de un pesimismo útil "que templa el alma, le revela a veces energías desconocidas y le descubre derroteros antes ignorados, abriéndonos así una puerta al mismo tiempo que nos cierra otra..." (Zozaya 1889, II, pág. 197).

5 Antonio Zozaya (1859-1943) comenzó a publicar hacia 1880 una "Biblioteca Económica Filosófica" que superaba el centenar de volúmenes en los años de la $2^{\mathbf{a}}$ República. 
El traductor intentaba refutar la afirmación fundamental del pesimismo sistemático que proclamaba "el mal invencible, el dolor esencial a la vida y la inutilidad de todos los esfuerzos que el hombre lleva a cabo para levantarse del lodo en que fatalmente ha de volver a caer." Tal vez fuera ésta la interpretación más extendida entre los seguidores españoles de Schopenhauer: destruir para crear, jugar al pesimismo para estimular la actividad ${ }^{6}$. En medio de esta suavización de la doctrina del pesimismo estuvo, sin duda, la lectura, o la divulgación, más o menos superficial, de Nietzsche desde 1900.

Zozaya no dudaba en calificar de tópicos "el aborrecimiento de la vida" y la consiguiente desvalorización de la realidad, porque - a su parecer realista- "la plenitud de la vida es contraria al dolor psicológico. No hay dolor físico allá donde la función es perfecta. El dolor se opone a la normalidad de las funciones" (Zozaya 1889, II, pág. 201). Y recurría a Claude Bernard para rechazar la relación causal entre el miedo a la muerte y el odio a la vida. Hay un Mundo objetivo fuera del sujeto y el placer consiste en el equilibrio de la sensibilidad subjetiva con los estímulos y excitaciones de la realidad circundante:

¿Diremos por esto que es patrimonio del hombre la felicidad? En modo alguno, porque en la tierra no es su patrimonio la vida completa, sin obstáculos y sin término. Pero sí que el dolor no es esencial a la vida, que no es su carácter positivo, como afirma el pesimismo sistemático, y que más cuerdo que el optimista que se hace merecedor del sarcasmo volteriano y que el sombrío pesimista que maldice la vida porque se acaba pronto y tiene muchos enemigos, es aquel que, feliz, se entrega a la alegría, no a la embriaguez, que desdichado, se abandona a la tristeza, no a la desesperación, que procura establecer entre sus facultades y el mundo ambiente el debido equilibrio y mostrándose digno de su racionalidad, espera su hora postrera para decir con Catón: Nec me vixisset penitet, no me pesa haber vivido (Zozaya, 1889, II, pág. 204).

\section{La receptividad de los más jóvenes}

Pero Parerga y paralipomena, más allá de la voluntad de su traductor, contenía sugerencias que podían estimular un cambio de sensibilidad estética e, incluso, alimentar la formulación poética simbolista: el prestigio del conocimiento altruista, característico de los primeros años de la vida, que facilita la nostalgia lírica y

6 Según Adalbert Hämel (1926, págs. 43-45) este pragmatismo, tan arraigado en el tradicional pesimismo del pensamiento español -que Schopenhauer conocía y admiraba-, establecería la diferencia con el pesimismo del filósofo alemán, encerrado en un círculo insuperable "alfa y omega de su credo". Gracián y otros pensadores españoles pesimistas "aspiran a vencer la voluntad de la vida", mientras que Schopenhauer tiene la facultad de destruir, pero no la de construir. Esta tradición española -añado yo- facilitaría, por ejemplo, la reorientación de la obra literaria de Martínez Ruiz a partir de su deuda intelectual con Schopenhauer, expresada en La Voluntad como redescubrimiento de "las recias potencialidades del yo", reducción de la realidad a las imágenes de la conciencia y dignificación moral de la vida contemplativa (véase Krause 1955, págs. 151, 222-223). 
aviva el tópico del regreso a la infancia; la fuente de la esperanza siempre defraudada que engendra descontento: "imágenes engañosas de un vago ensueño de febrilidad" (Schopenhauer, [1851] 1889, II, pág. 146); el efecto pernicioso de la sucesión de las edades, primero como aspiración insatisfecha, después como aprensión de la desdicha; la melancolía y el desengaño, frutos de la experiencia. En suma el carácter quimérico de la felicidad y la realidad del sufrimiento...

¿Qué efecto produjo este texto en lectores jóvenes? Algo sabemos por Pío Baroja cuando cuenta que lo leyó al filo de su publicación y le sirvió para reconciliarse con la filosofía ${ }^{7}$. Aquella lectura - pese a parecerle en parte cándida- neutralizó su exaltación humanitaria y sentimental induciéndole "a la no acción", a la piedad y al conocimiento de las doctrinas budistas (Baroja [1944a] 1951, págs. 199, 216-218). ${ }^{8}$ Corrobora esta declaración la presencia del pensamiento de Schopenhauer en su tesis doctoral (1896) donde, tras aludir al pesimismo del filósofo y considerar el dolor como noumeno o cosa en sí, fruto de un proceso cenestésico _-"summun de sensaciones", "materia prima de la sensibilidad"-, y después de apoyarse en el aforismo del Ecclesiastés "quien añade ciencia añade dolor", en Sakia Muni y en la experiencia atormentada de ciertos poetas modernos (Byron, Leopardi, Heine), llega a un par de conclusiones en las que no es difícil reconocer la doctrina que las inspira:

6. La capacidad para sentir el dolor físico en las especies y en las razas está en razón directa de la inteligencia. En los individuos la sensibilidad para el dolor físico es un resultado de su temperamento y género de vida.

7. La percepción del dolor moral en las razas y en los individuos es tanto más perfecta cuanto más desarrollada esté la inteligencia. (Baroja [1896] 1973, II, pág. 406).

Aunque inicialmente el joven Baroja busque concretar en cierto determinismo positivista la identidad entre espíritu y materia (voluntad, libertad y alma condicionados por la bioquímica) ${ }^{y}$ y reserve los más angustiosos efectos de la "fatiga de

\footnotetext{
7 "El deseo de asomarme al mundo filosófico me produjo, siendo estudiante, la lectura del libro de Patología, del doctor Letamendi; con este objeto compré, en una edición económica que dirigía Zozaya, los libros de Kant, Fichte y Schopenhauer. Leí primero La Ciencia del conocimiento de Fichte, y no entendí nada. Esto me produjo una verdadera indignación contra el autor y contra el traductor. ¿Sería la filosofía una mixtificación, como creen los artistas y los dependientes de comercio? El leer el libro Parerga y paralipomena, me reconcilió con la filosofía. Después compré, en francés, la Crítica de la razón pura, El mundo cono voluntad y como representación. y algunas otras obras" (Baroja [1917] 1977, págs. 87-88).

8 Al reconstruir, con fuerte componente autobiográfico, los años de formación de Luis Murguía en La sensualidad pervertida ([1920] 1948, p. 892), Baroja matiza el efecto de su primera lectura de Schopenhauer: "Todo lo que dice este hombre como reserva y suspicacia me pareció que lo sabîa desde la infancia. [...] A mí, al menos, no me quitó las ilusiones; al revés, me dio la impresiốn de que el autor creía en muchas cosas fantásticas que yo había desechado ya en mi interior".

9 Véase un ejemplo en clave irónica en "La vida de los átomos", cuya primera versión data de diciembre de 1893 ["Danza de átomos"] (Baroja [1900] 1948, VI, págs. 1041-1044; y 1972, págs. 6467). La versión definitiva de este relato contiene una escéptica referencia a la Psicología celular de
} 
vivir" a los humildes, excluidos del opulento castillo ${ }^{10}$, se diría que trata de conciliar esta doble preocupación cientificista y social con ciertos motivos schopenhauerianos -metafísicos o morales-, muy presentes en algunos cuentos de Vidas sombrías: el sueño de la vida ("Médium"); la universalidad del dolor y la imposibilidad de sustraerse a sus efectos, la inutilidad de la experiencia y el conocimiento que añade dolor ("Marichu"); la disolución de la conciencia individual en la muerte ("Playa de otoño"); la piedad ("Bondad oculta"), a la que se añade la unidad de la vida de humana y animal ("Piedad postrera") y la función liberadora de la poesía ("Nihil"). Tal vez la síntesis más lograda de esta presencia de Schopenhauer, quizá todavía exenta de la corrección vitalista nietzscheana, se halle en "Parábola" cuya primera versión -"El bien supremo"- apareció en La Justicia (6-1-1894): allí se evoca la vida entre tinieblas, la misteriosa ciudad de la Nirvana "en donde se es sin ser, y en donde se duerme el eterno sueño del aniquilamiento"; se sugiere el viaje iniciático en pos de la dicha que reconduce circularmente a la resignación y se poetiza la espera de la muerte,

la dulce hora de perder la personalidad en el crepúsculo del pasado y de fundirme en la augusta inconsciencia, como un rayo de sol en las masas azules de los mares" (Baroja [1900] 1948, VI, 993-994.

Algo cabría apuntar acerca de Unamuno y su temprano conocimiento de Schopenhauer, como uno de sus primeros traductores españoles, que quizás explicaría algunas ironías sobre el genio de la especie en clave de realismo descarnado, o simbolismo realista, en su Amor y pedagogía. "Fúnebre sucesión de sombras que van de la nada a la nada", es el sueño de la vida para don Fulgencio Entrambosmares, cuya conciencia personal de la voluntad de vivir se muestra en desajuste patético con otras concepciones positivistas de la muerte como sencilla y aproblemática "cesación de la vida" individual:

¿Qué soy yo? Un hombre que tiene conciencia de que vive, que se manda vivir y no que se deja vivir, un hombre que quiere vivir, Apolodoro, vivir, vivir, vivir. Yo tengo voluntad y no resignación de vivir; yo no me resigno a morir porque quiero vivir; no, no me resigno a morir, no me resigno... iy moriét!"

Ernesto Haeckel, para quien la sensación manifestaba la energía de la substancia que desde los átomos se elevaba hasta la actividad intelectual, de modo que la materia y el espíritu se fundían en una concepción monista. Este libro contribuyó a la formación científica de otros jóvenes escritores de la regencia, como Llanas Aguilaniedo (Broto Salanova, 1992, págs. 43 y 53).

10 En "Nihil" (Baroja [1900], 1948, VI, págs. 1009-1012.

"Unamuno 1902. pp. 172-173. Schopenhauer es mencionado entre los grandes pensadores, que pudieron dar cima a sus proyectos filosóficos y de los que don Fulgencio trata de sacar el promedio de vida de que dispone para terminar su propia obra: "Y yo me decía: "hasta que las lleve a cabo todas no me muero". ¡Y no poder tener fe... no poder tener fe en mi inmortalidad! ¿Por qué no he de ser yo el primer hombre que no se muera? ¿es acaso una necesidad metafísica la muerte? (Unamuno 1902, p. 174). 
Acaso la noción de intrahistoria pudiera encontrar asimismo fundamento en algunas reflexiones sobre el valor histórico de la vida cotidiana transfigurada por el arte, contenidas en el Libro III ( $\$ 48)$ de El Mundo como voluntad y representación $n^{12}$.

Tampoco el joven Martínez Ruiz debió de sustraerse a una pronta lectura, si aceptamos que sus seudónimos valencianos - Cándido y Ahrimán- pudieran proceder de sendos pasajes del mismo Libro III de El mundo como Voluntad y Representación, aunque sin descartar la opción leopardiana, como sugirió Anna Krause (1955, pág. 79). En cualquier caso, su conocimiento de Schopenhauer aparece documentado ya en uno de sus primeros artículos valencianos al mencionar de pasada el papel del filósofo en la formación de Bakunin (Martínez Ruiz 1894). No faltan, más tarde, otros vacilantes indicios literarios durante su campaña en El País, como la referencia al arte, lenitivo del dolor de vivir ("El ocaso de una gloria", 18-121896 y "Delirante...", 21-12-1896); la nostálgica afirmación de la vida contemplativa, de la soledad y la meditación como fuentes de trabajo fecundo y voluntario ("Crónica", 4-1 y 9-2-1897), el recurso irónico al motivo del suicidio ("Crónica", 19-1-1897), que se anticipan en el tiempo a la conocida paráfrasis en torno al Schopenhauer educador de Nietzsche en La voluntad, descrita por Krause (1955, págs. 89-95). Su escepticismo, en el que habría que contar ya seguramente sus lecturas barrocas, entre ellas la de Gracián que, no lo olvidemos, era santo de la devoción española del filósofo alemán (Morel Fatio 1910), le conduce a ir refundiendo melancólicamentc el vanitas vanitatum con la convicción determinista, en un fermento integrador de diversas ideas nutricias. Baste recordar algún párrafo de las últimas páginas de La sociología criminal (1899) para advertir el cambio profundo que se estaba produciendo en el anarquista Martínez Ruiz en vías de ir adquiriendo la sensitiva piel de Azorín:

Todo es determinado en la creación; todo es ocasionado; todo es necescirio. El determinismo es la imperante ley universal. Realiza el hombre sus actos como el tigre que desgarra las carnes de su víctima; como la flor que abre su corola; como la catarata que se despeña en el abismo. Ni hombre, ni tigre, ni flor, ni catarata son responsables de su manera de obrar... [...]

Nada es eterno: todo es mudable. Surgen a cada momento en el espacio mundos nuevos y acábanse los que cumplieron ya su hora. La materia sigue sin cesar su evolución al infinito, cambiando, transformándose, muriendo por renacer en formas nuevas. El hombre no es una excepción del aniquilamiento universal. Como se acabaron las faunas de otros tiempos, se acabará también el hombre, y no quedarán huellas de su genio, de sus monumentos, de sus civilizaciones. Apagaráse el sol; cesará la tierra de ser morada propia del hombre, y perecerá lentamente la raza entera...

12 “...una escena de la vida diaria puede puede tener la más alta significación interior siempre que nos muestre con viva luz los secretos de la naturaleza y de la conducta humana". (Schopenhater [1818-1844] 1960, Il, pág. 231). 
...Y entonces, desierta la Tierra, rodando desolada y estéril, entre profundas tinieblas, por el espacio inmenso, ¿para qué habrán servido nuestros afanes, nuestras luchas, nuestros entusiasmos, nuestros odios? (Martínez Ruiz, 1899, págs. 204-207).

En cuanto a la conciencia dolorosa de vivir que Antonio Machado trataba de acallar hundiéndose en el pasado "que el soñador considera como verdadera vida", ya fue advertida hace tiempo por Hans Jeschke (1944, pág. 112). Un maduro testimonio machadiano (1919-24) valoraba más la fuerza poética de Schopenhauer y su capacidad para revelar las honduras del yo, que su "verdad filosófica":

En Schopenhauer el mundo alcanza la máxima opacidad, es todo él ceguera, acefalia, impulso ciego. [...] Para Schopenhauer la esencial realidad es la voluntad, de la cual nada podremos decir, porque esta voluntad es en principio, no hay categoría intelectiva que le apliquemos para definirla, ni posición teórica desde donde podamos intuirla; de ella ha brotado el mundo de la representación, el sueño búdico, la vana apariencia en que se ahoga la conciencia humana. Si de algún modo se nos revela - en nuestro yo, donde el velo de Maya alcazan alguna transparencia- es como dolor, ansia de no ser, apetencia de nirvana y de aniquilamiento de la personalidad. (Machado 1957, pág. 27) ${ }^{13}$.

\section{Schopenhauer en España, a través de Nietzsche, Nordau, Gener y Caro}

Mediados los años veinte, Rafael Cansinos Assens, empeñado en disociar el espíritu crítico del 98 y la neurosis creativa modernista, trataba de definir ese contradictorio pesimismo vitalista de la "generación del 900", del que antes hablábamos. Según el crítico, la abulia práctica - "inhibición absoluta para las ideas" - se transformaba en activa "orgía creadora" por impulso nietzscheano cuando se trataba del arte:

Lo que esta generación quiere no son verdades intelectuales, sino sinceridad sentimental, rosas y música. Lo que le interesa ante todo, aunque viva sumida en artísticos sueños, es la vida, la Vida, que en sus libros tiene una mayúscula hierática y está erigida como sobre un ara. Y no menos le interesan la Muerte y el Misterio. Es una generación pesimista, que cruza sus brazos para la acción, pero que siente, sin embargo anhelos de una epopeya lírica que cumple en su obra artística. Esta generación extática, sin voluntad y sin ideales, sin un amor vivo hacia nada, tiene su loca orgía profusa a lo Rubens en su obra. En ella cumple su anhelo nietzscheano de superarse y arma sus naves y las impulsa hacia las más lejanas Thules..." (Cansinos 1925, pág. 357).

Más o menos, por las mismas fechas Antonio Machado (1957, pág. 27) anotaba en Los complementarios:

Nosotros hemos vivido el poema de Schopenhauer con música de Wagner -y Nietzsche, "claqueur" primero y luego reventador...

13 Más tarde, Juan de Mairena (Machado, 1936, pág. 319) acabaría reconociéndole categoría de filósofo sistemático al compararlo con Nietzsche, por quien ya en 1903 mostraba poca simpatía (véase Alonso 1995, pág. 8). 
La asociación, confusión o solapamiento de Schopenhauer y Nietzsche es uno de los aspectos cruciales de la recepción europea del autor de El mundo como Voluntad y Representación. Baroja (1899) ${ }^{14}$ aseguraba haber conocido a Nietzsche a través de Nordau en versión francesa, por tanto después de 1894. Al revisar entonces las fuentes del pensamiento nietzscheano, apuntaba:

Como metafísico, Nietzsche no tiene nada de original. Su concepción del mundo es la misma que la de Schopenhauer ${ }^{15}$, todo es voluntad y todo representación. La tendencia piadosa de Schopenhauer es la que molesta a Nietzsche, a este pobre cantor de fuerzas que no tiene ${ }^{16}$.

Ciertamente, poca novedad ofrece su posición si recordamos que Nordau ya había acusado a la filosofía de la voluntad de Nietzsche de ser un pastiche de Schopenhauer, cuya obra había dado "dirección a su pensamiento y color a su lenguaje" sin más novedad que un postizo de su cosecha al convertir la voluntad de conservación (genio de la especie) en voluntad de poder que el austriaco tildaba de infantil (Nordau, 1894, págs. 353-354). Por su lectura prejuiciosa, rechazaba como degenerada toda filosofía de la renunciación - aquietamiento, misticismo o nirvana ${ }^{17}$ - como el más alto ideal del espíritu humano, cuyo origen atribuía a Schopenhauer sin advertir que éste consideraba la santidad como consuelo del conocimiento, inútil, en último término, ante la nada.

14 Recordemos que en este conocido artículo de Revista Nueva -"Nietzsche y su filosofía"Baroja muestra sus reservas ante el libro de Nordau por el que desfilaba "lo mejor de la humanidad presente no con nimbos de luz ni con aureolas de gloria, sino desquiciada, histérica, con la espuma de la epilepsia en la boca y con el temblor de la ataxia en las piernas". Lisa E. Davis (1977, págs. 321-323), en su conocido estudio sobre la recepción española de Nordau, consideraba que Pío Baroja era el único escritor noventayochista en el que se detectaban "claramente las tensiones entre la nueva literatura y la estética de orientación social a la moda decimonónica". Tengo la impresión de que se trata de un fenómeno más extenso, del que no se podría excluir a Martínez Ruiz o a Llanas Aguilaniedo, entre los autores que estudiamos.

15 La subordinación de Nietzsche a Schopenhauer en la apreciación de Baroja (a su vez, supeditada a la de Nordau), ya fue advertida por Gonzalo Sobejano (1967, págs. 63 y 122). Baroja había escrito en "Figurines literarios" (El País, 24-4-1899) que la filosofía de Nietzsche era "el detritus de la filosofía de Schopenhauer" y así seguía pensándolo cuando incorporó este artículo al quinto volumen de sus Memorias (Baroja, 1948a, pág. 228). En El escritor según él y según los críticos (Baroja, 1944, págs. 295-318) reproduce, entre complacido y escéptico, algunos pasajes de la tesis doctoral del alemán Helmut Demuth (1937) quien atribuye a la amistad de Pablo Schmitz el conocimiento de Nietzsche que vino "a completar el mundo de Baroja, cuya base fue Schopenhauer." Al lado del vencimiento del dolor por el conocimiento, pondría Baroja el vencimiento por medio de la acción. "Nietzsche, que no en vano era un descendiente de Schopenhauer, le daba el reverso de la doctrina de la voluntad, y con ella la conciliación entre voluntad y conocimiento" (Baroja, 1944, págs. 304-311). El novelista (1945, págs. 68-69) optaría en sus últimos años por un ideal de futuro que armonizara la fuerza y la piedad con ayuda de la ciencia, concertando implícitamente el pensamiento de ambos filósofos.

is En Los dolores del nundo (Schopenhauer 1904, pág. 43) se puede leer que la piedad, base de la moral, nacía del sentimiento de la identidad de todos los hombres y de todos los seres. La idea está presente en cuentos juveniles de Baroja, como "Piedad postrera" (Vidas sombrias).

17 "Los degenerados y los alienados son el público predestinado de Schopenhauer y de Édouard de Hartmann, y les basta conocer el budismo para convertirse" (Nordau, 1894, I, 39). 
Por las mismas fechas en que Baroja leía a Nordau, Pompeyo Gener publicaba (febrero de 1894) su Literaturas malsanas, fechado en abril del año anterior, que incluía una apología del Schopenhauer moralista prescindiendo de su dimensión metafísica, cosa comprensible en el progresismo de un positivista con talante integrador, en discrepancia con la actitud del francés Érasme $\mathrm{M}^{\mathrm{C}} \mathrm{Caro}$, muy duro con el filósofo alemán, cuyo libro El pesimismo en el siglo XIX apareció en traducción anónima hacia $1893^{18}$. Gener en La muerte y el diablo ( $1^{\mathrm{a}}$ ed. española, 1883) ya había arremetido contra el pesimismo de Hartmann, pero en Literaturas malsanas, matiza claramente su posición con respecto a Entartung, obra de la que tenía noticia pero no había leído, ni siquiera en francés, antes de terminar su libro. Gener admitía su coincidencia con Nordau en el asunto pero no en sus conclusiones, aunque el catalán terminaba su ensayo de modo contradictorio con una drástica "terapéutica estética" que, tras definir la literatura como "fermento anímico capaz de engendrar almas similares" y proclamar el superhombre in fieri-artista, sabio y justo-, declaraba "mal sano, criminal y punible, por delito de lesa humanidad" a quien propendiera a deprimir la vida, matar la evolución, rebajar el impulso humano o hacer aceptable el dolor. Para él, en definitiva, el arte debía "producir altos estados de vitalidad" y el Estado debía velar por que así fuera (Gener, 1894, págs. 379-381). Pese a ello, en nota post scriptum, se contradecía acusando al escritor austriaco de preconizar un arte dirigido, en el que la expresión de las ideas debía sujetarse a "contornos matemáticamente definidos". A su juicio, el sistema de Nordau condenaba la imaginación desconociendo el poder creativo de la intuición, "fuerza interna de proyección del ser [...] que produce el desdoble del yo por plétora de sentimiento" hasta constituir "la mitad más esencial del ser Humano, esa base orgánica, inconciente, pero foco de energías y causa de toda creación"'(Gener, 1894, págs. 389-390). Se comprende que, con tales vacilaciones, arremetiera contra el "malentendido" del vulgarizado pesimismo schopenhaueriano, cooperando velis nolis a neutralizarlo entre los escritores jóvenes, contribuyendo al desarrollo de un ilusorio pragmatismo progresista combinado con ideales de pureza filosófica.

Sin negar absolutamente sus tendencias pesimistas, Schopenhauer, según su exégeta catalán, estudiaba los males "sólo para señalar la manera de curarlos". Si exageró en alguna ocasión fue por "su mismo amor a los que sufren" de manera que "el pesimismo moderno vendría en todo caso de la mala o de la poca comprensión de sus teorías" (Gener, 1894, págs. 290-291). Hay vibración retórica en su estilo cuando trata de definir la moral "pacificadora" del pensador alemán:

18 Este libro constituye otra vía de segunda mano, sin duda muy transitada, para el conocimiento del asunto de la recepción española de Schopenhauer en el fin de siglo. A él recurrió abusivamente José Deleito y Piñuela en su tendencioso, aunque estimable, estudio neorregeneracionista El sentimiento de tristeza en la literatura contemporánea (1922), lleno de tópicos sobre el pesimismo del filósofo alemán (vid. págs. 31-40). 
Es un filósofo tierno; un pesimista suave y resignado. No retrocede ante los terrores del espíritu, ni ante las flaquezas de la carne. [...] Sí, Schopenhauer cree que el mal domina en el mundo, pero no saborea la ruina, no se alegra de desastre, no halla placer en la catástrofe; y cuando faltan medicamentos que lo curen, procura encontrar narcóticos morales que calmen la sensibilidad dolori$\mathrm{da}$ a fin de que la sacudida nerviosa sea menos violenta. [...] No rechaza la vida, no predica la melancolía; al contrario, aleja del suicidio. No es ni un desesperado, ni un sarcástico; nada de esto; es un organizador que sueña en bien de la Humanidad... [...] Consuela y reconforta. [...] Enaltece al hombre, acrecentando sus más íntimos instintos de libertad. Le enseña que él es el único artesano, responsable ante sí mismo, de las felicidades o de las desgracias que provocara, en su falta de saber; y que la oscuridad de la propia conciencia, constituye un peligro inmediato y permanente (Gener, 1894, págs. 294-296) ${ }^{19}$.

Pompeyo Gener, cuya recepción entre la juventud literaria española de la regencia reclama mayor atención ${ }^{20}$, muy desmerecido por sus chocantes anécdotas biográficas - coses d'en Peius!_, estimuló la propuesta de su discípulo Llanas Aguilaniedo ${ }^{21}$ que desarrolló con su emotivismo una suerte de legitimación estética de la tristeza, la histeria y el pesimismo, como paradójicas fuentes de energía creadora (patotelia o patorexia, en cuanto estados no sólo morbosos sino también de emoción, deseo ardiente e impulso anímico), con la complacencia de sus jóvenes compañeros de promoción, deseosos de conciliar hiperestesia y regeneración. En el límite, por tanto, entre el positivismo y la rehabilitación de emociones y sensaciones como materia prima de la estética modernista.

19 En efecto, para Schopenhauer el suicida ama la vida; al destruir su cuerpo no renuncia a la voluntad de vivir, sino a la vida insufrible; va contra el dolor de vivir no contra la voluntad metafísica de vivir como cosa en sí, a la que es indiferente el destino de los individuos. Así, la voluntad de vivir se manifiesta tanto en el hecho de darse muerte, como en el placer de la conservación personal (Schopenhauer [1818-1844] 1960, III, págs. 102-105).

20 Comparto los argumentos de Consuelo Triviño (1995) en su reivindicación del escritor catalán en relación con el modernismo.

21 En el caso de Llanas Aguilaniedo el ejemplo de Gener es determinante, como ha documentado Justo Broto Salanova tanto en su excelente introducción a Alma contemporánea (Llanas 1991, págs. XXVIII-XXXVIIV) como en Un olvidado... (Broto 1992, págs. 64 y ss.). Aunque el biógrafo no menciona a Schopenhauer entre las referencias a la formación filosófica del autor (1992, págs. 71-74), sí registra una alusión del oscense al filósofo alemán, en 1894, a propósito de la "melodía sinestésica, mensaje del infinito" que se desprende de la contemplación de la Naturaleza y penetra "confusamente los arcanos que la razón se esfuerza en vano por alcanzar" (1992, pág. 56). Que Llanas no era ajeno a la inspiración schopenhaueriana se advierte también en algunos pasajes de su primera novela, En el jardín del amor (1902), construida - como asimismo insinúa Broto (1992, pág. 325)— sobre la contradicción que supone que la melancólica protagonista, María de los Ángeles, se sustraiga al "genio de la especie" y declare su homoerotismo, sumiendo la propuesta emotivista en el más oscuro morbo decadente y en el simbolismo más vago. A través de una conciencia femenina diferenciada, el personaje busca apoyo en lo oscuro del arte (Llanas 1902, págs. 93-94), admite que "el descanso final es la gran solución" (id., pág. 101), cree que la felicidad está en la amputación de la inteligencia (id., pág. 104) y que su vida de enferma la enfrenta cada día al destino inexorable, "la negación, la nada eterna e invariable (id., pág. 105); desea la inacción física, pero su espíritu activo se rebela desesperadamente (id., págs. 106-107) y lamenta que su falta de voluntad individual le impida incluso el aquietamiento místico (id. págs. 121123). Sobre el escritor oscense también puede verse: Mainer (1989); Ara Torralba (1990) y Calvo Carilla (1990). 


\section{Caminos de perfección: la busca del aquietamiento espiritual en la naturaleza}

Ya hemos comentado cómo el jovencísimo Martínez Ruiz, en medio de su tormentoso anarquismo, no sólo se había mostrado sensible a la estética de la muerte como consuelo ${ }^{22}$, sino que anticipaba fórmulas de un relativo aquietamiento espiritual basado en Ia fuga del mundo urbano y viciado hacia las "salmodias melancólicas" de los pinos montaraces o hacia la vida "tranquila, reposada, profunda" de las ciudades muertas, de calles solitarias y silenciosas, de caserones antiguos donde vivir días fecundos de soledad y meditación ("Crónica", El Pais, 4-1-1897). Incluso llega a esbozar un modelo literario de fervor por la Naturaleza, anticipo de tendencias posteriores de su arte, desarrolladas a partir de La Voluntad, y que anuncian una cierta mística del paisaje, donde la sensualidad no oscurece un vivo proyecto de ascetismo sensual y paganizante, que insinúa en el escritor urbano, perdido en las perturbadoras luchas cotidianas, una compensatoria liberación regeneradora precedente de un paradigma muy frecuentado por los narradores de los años siguientes. Así, en 1897, alude por personaje interpuesto al proyecto imaginario de un libro, que se titularía Paisajes y que prefigura su futura poética:

serie de cuadros sin figuras, de manchas de color, de visiones... de estados de alma ante un pedazo de Naturaleza, sensaciones de la madre Tierra. [...] ...impresión hondísima ante un grupo de árboles, ante una roca gris que se yergue al borde del mar, ante un montón de hojas secas, amarillentas que el viento hace jugar a lo largo de las alamedas, en el otoño, cuando el cielo es de color de plomo, y no tienen flores los jardines, ni el campo follaje y ruidos alegres...

Ascetismo de dudosa trascendencia, como no sea el placer o gloria estética, sobria melancolía que, por supuesto, no tiene por qué responder puntualmente a señuelos schopenhauerianos pero que acaso no le ronde muy lejos. Vías de perfección por el apartamiento que, como es bien sabido, darían sus frutos más granados hacia 1902 (Martínez Ruiz, Baroja, Llanas Aguilaniedo...). Pero antes habían alcanzado también a algún autor tan alejado aparentemente de las tensiones estéticas finiseculares como Ricardo Macías Picavea que, en el primer volumen de La Tierra de Campos (1897), bajo el signo de ese pesimismo activo tan propio de la voluntad regeneradora, testimonia, entre convicciones positivistas, actitudes de una juventud idealista, sensible a la llamada de la naturaleza originaria, donde hallar la paz alterada por la ciudad industrial. Cierto que esta novela se pierde en la retórica del melodrama catastrófico pero ello no enturbia el sentido último de pasajes que evidencian la sensibilidad de un escritor del 68 , tangente de modo epigonal con las neurotizadas actitudes de los fin de siglo, sobre todo cuando trata de captar sutiles cambios en la interiodad sensitiva de un personaje de formación krausopositivista, Manuel Bermejo, pretendido regenerador de Valdecastro, decepcionado tras haber

22 “Para qué vivir? La muerte era un consuelo, y a la muerte invocaba, llamándola tiernamente, con voluptuosidad; deseando tan sólo, como el sublime poeta de las tristezas, Quel di ch'io peghi addormentato el volto/ Nul tuo virgineo seno" (Martínez Ruiz, 1895). 
vivido la experiencia de la gran urbe y haber idealizado el mundo rural. Aunque desde una perspectiva todavía resistente a la penumbra simbolista, la conciencia diferenciada del yo, el "vicio" introspectivo, confiere a estos pasajes algo de la "modernidad epistemológica" (no tanto de la estética) que Germán Gullón (1992, págs. 97-99) ha considerado como indicio de la crisis de la novela realista, a propósito de la unamuniana Paz en la guerra (publicada el mismo año):

El generoso espíritu del joven Bermejo, educado en aquellos idealismos de la pura conciencia que esterilizaron casi una generación en la época revolucionaria, sentíase contrariado de veras. ¡Él, que había soñado huir las pedestres ruindades de la profesión refugiándose en la soledad amiga de los campos, donde pensó encontrar gratos motivos de estudio, animadores estímulos del interés, horizontes nuevos a su vida, veíase sin saber cómo sumergido otra vez en el sucio fango de las vilezas humanas! [...] Le acometían accesos de amargura insondable, y se lanzaba entonces solitario a paseos larguísimos, perdiéndose al través de mil sendas en las inmensidades del mar de arcilla. Allí se entregaba sin freno al vértigo del diálogo interior, vicio de introspección adquirido en Madrid en cierta sala del Ateneo antiguo de la calle de la Montera, y, más aún, en el Círculo filosófico, donde fue presentado por distinguido profesor krausista que le entusiasmó en Ávila con sus explicaciones de apóstol: ¡desolada disciplina intelectual que en el vacío de toda realidad sustituida por no sé qué engañosa penumbra poblada de fantasmas, exprime hasta la tortura el sujeto, como en esos casos de autofagia cuando, imposibilitada la máquina digestiva para ingerir y asimilarse reparador alimento, devórase el ser vivo a sí propio hasta consumirse en el más triste y miserable de los suicidios" (Macías 1897, I, págs. 199-200).

Pero aún más llamativo resulta algún eco de schopenhauerismo implícito en la novela de Macías Picavea, que presupone distinción conflictiva entre la voluntad universal y la individual, entre una realidad irracionalista (otro indicio de la moderna angustia) y un fatalismo cazurro (condena irónica de la acción regeneradora):

¡Qué sorpresas tan desacordes, tan inopinadas, tan ilógicas esconde la realidad! ¡La realidad!.... un genio monstruoso, malévolo, burlón, ocupado eternamente en chafarnos el ideal y... reírse de los proyectos matemáticos de nuestra lógica... ¡Está bueno esto!...[...] me escapaba de Madrid y Barcelona, buscando sumirme en la nada gris de esta tierra muerta..., y ahora resulta que en tal rincón con apariencias de mar petrificado, me saltean y entrecogen olas y tormentas dotadas de energías jamás por mí sentidas!... ¿Qué es la voluntad humana, la voluntad de un pobre espíritu, ante la voluntad aplastadora de... de eso..., del gran mundo... de lo desconocido!... ¿Y qué?... ¡Valiente tontería... darme a mí ahora por lo subjetivo y metafísico! ¡Bobada! No hay nada mejor, ni tan cómodo, ni tan hermoso, como el principio activo que va encerrado en esta dicho frecuente de mis paisanos: “'Sea lo que Dios quiera!” (Macías, I, págs. 236237).

Como se sabe, en las novelas canónicas más indiscutibles de 1902, —La voluntad, Camino de perfección...- fluctúan el impulso regenerador y la abulia esteticista, de modo que el fondo pesimista se reviste de una voluntad de acción con inclinación al acto fallido. En semejante línea, oscurecido por los modelos más 
conocidos de estas fugas aquietadoras y dependiente de ellas, convendría considerar, por su rareza, el caso de Isaac Muñoz Llorente (1881-1925) en quien no es descabellado suponer un cierto conocimiento de Schopenhauer, patente en su primera novela Vida, publicada en 1904. Amelina Correa, autora de un estudio ejemplar sobre su vida y obra, no considera tal posibilidad, aunque sí ha advertido en esta juvenil autobiografía espiritual el peso de Nordau y ha señalado similitudes con el Camino de perfección barojiano, cuyo impacto hay que admitir en el joven escritor granadino (Correa, 1996, págs. 320-326). Aventurándonos por las movedizas arenas de la hipótesis, podríamos suponer que Schopenhauer pudo Ilegarle a Isaac Muñoz filtrado por la novela de Baroja y -cómo no-por La voluntad de Martínez Ruiz. Tristeza y dolor de vivir, manifestaciones extremadas de un erotismo crispado, impulsado por el instinto, "genio de la especie", sublimado por la purificación mística, se hallan en Vida, en un esquema que recuerda aspectos del Libro IV de El Mundo como Voluntad y Representación: desilusión, metamorfosis del sufrimiento, el ascetismo como negación del "querer vivir" y el arte como liberación pasajera. Relato en fuga, más vitalista que estoico, simbolista en la intención y en el lenguaje de prosa cincelada, donde se concibe el mundo como camino recorrido multidireccionalmente en sucesivas salidas-experiencias quijotescas, que comportan conocimiento progresivo, poniendo de manifiesto una amplia escala de valores, desde lo más íntimo hasta lo social, y conducen a la anulación de la voluntad por una forma de santidad sensual. Solución que Schopenhauer ([1818-1844] 1969, III, págs. 109-112; 1904, págs. 49 y ss.), claro es, no propugna pero respeta como una de las ilusorias manifestaciones de la voluntad de vivir para sobreponerse a la nada. Residuos naturalistas, con un final que impone la tesis de la armonía mística del individuo y la naturaleza, fruto de una experiencia vivida entre símbolos e intuiciones, haciendo realidad la confusa aspiración de aquietamiento fecundo cuyos primeros indicios vimos en el Martínez Ruiz de 1897:

Daniel, por un proceso psíquico, que semejaba el correr de un arroyuelo hasta perderse en el mar, había llegado a un supremo estado, en que la conciencia de la vida creada por los hombres desaparece, y en que el yo, rebelde y orgulloso, se funde en el todo como yerbecilla que se adhiere al tronco nudoso de un árbol gigantesco (Muñoz 1904, pág. 95).

Curioso y admirable cruce de dos venas literarias - la naturalista y la simbolista - sin duda presentes de consuno como formas de la modernidad en el aprendizaje literario de Isaac Muñoz. No olvidemos que para Nordau y para su sosia subpirenaico Pompeyo Gener, Zola y el zolismo era otra de las caras de la degeneración literaria. Como igualmente lo era para la línea del positivismo regeneracionista, refractario de oficio a las vacilaciones simbolistas, muy patente en la "poética" del citado Macías Picavea cuando prefería la "información llena de positivos datos" y el discurrir "con criterio objetivo y realista" a las "mezclas naturalistas, parnasianas, diabólicas, ibsenistas, rusófilas... ni de ninguna otra estofa" (Macías 1897, I, XXVIII-XXIX), lo que obviamente no significaba impermeabilidad 
a los estados subjetivos de sus personajes, expresados con ayuda de símbolos reveladores de la "realidad interior".

\section{Schopenhauer y el simbolismo. Pérez de Ayala contra Bonilla y San Martín}

Parece razonable admitir que el pensamiento del filósofo alemán, con su frágil visión del Mundo como una representación del sujeto destinada a desaparecer con él, constituía un estímulo para elaborar aquellas imágenes aproximativas a la Idea, que propiciaban el asedio poético simbolista. No aludimos ahora, claro está, al simbolismo conceptual y realista con que Galdós articuló sus primeras novelas contemporáneas, sino a aquel otro intuitivo y moderno (con sugestiones metafísicas), "frenesí místico" que comienza por el "cultivo del matiz" (Cansinos 1925, págs. 126-127). Schopenhauer había escrito:

Si queremos llegar a una comprensión más profunda de la esencia del mundo, es absolutamente necesario que aprendamos a distinguir la voluntad como cosa en sí, de su adecuada objetivación y luego los diferentes grados en que aparece cada vez más distinta y perfecta; es decir, las ideas mismas de la mera manifestación de esas ideas en las formas del principio de razón, que son el modo condicionado del conocimiento individual. [...] Entonces comprenderemos también cómo una misma Idea se nos aparece bajo diferentes formas y no se revela al individuo más que fragmentaria y sucesivamente (Schopenhauer [1818-1844] 1860, II, pág. 195).

La poesía como ansia de absoluto, sueño o ilusión desesperada e inasequible, las figuraciones narrativas al hilo contradictorio de la acción y el anhelo de la ataraxia, encontraban en su filosofía fundamento adecuado. Pero ¿cómo se veía la cuestión en España? Los textos teóricos desapasionados escasearon, en aquellos momentos de tensión estética que Manuel Machado denominó "guerra literaria". Precisamente la definición del arte como intuición de la Idea y su rechazo de la alegoría como abstracción conceptual, no intuitiva y, por tanto, ajena a la obra artística (Schopenhauer [1818-1844] 1960, págs. 236-240), dio ocasión a ciertas objeciones de Adolfo Bonilla y San Martín (1902) recogidas en una apretada memoria, con destino a una controvertida oposición a cátedra, pero de interés para pulsar el debate en torno al simbolismo artístico, tanto por su fecha de publicación como por el eco que obtuvo en un irritable Ramón Pérez de Ayala, recién llegado a Madrid y poeta simbolista en ciernes. El joven profesor (que citaba El mundo como Voluntad y Representación en alemán) no aceptaba la proposición schopenhaueriana de que la Idea, como todo lo intuitivo, se pudiera expresar de una manera enteramente directa y perfecta, sin necesidad de mediador alguno para manifestarse. Aunque Bonilla (1902, págs. 16-18) admitía que la Idea artística no podía reducirse a concepto, negaba la posibilidad de que su expresión pudiera ser perfecta porque el hombre no llega a comprender su esencia en toda su plenitud y por la necesidad misma de las mediaciones instrumentales y materiales. En cierto modo Bonilla, 
como hombre de su generación - había nacido en 1875- estaba dando argumentos condicionados para defender el simbolismo contemporáneo que apuntaba hacia un conocimiento fragmentario y sinestésico de la cosa en sí, con una expresividad fruto de la intuición lingüística, pero su argumentación se formulaba desde una perspectiva académica y positivista, quizás demasiado esquemática, fría en definitiva, que entraba en contradicción consigo misma cuando negaba explícitamente el simbolismo modernista porque, a su juicio, la mayor parte de sus producciones no llegaban al fondo sino que se detenían en las palabras ${ }^{2.3}$. Pérez de Ayala (un intelectual, estudiante de doctorado, filobohemio), quizá deseoso de llamar la atención, no se esforzó en entender a Bonilla (un joven docente universitario, atildado, sin pasión creadora) y se mostró muy cáustico con él, en la reseña que hizo del folleto en el diario republicano El País (1903, 4 de febrero), sin advertir que alguna de aquellas objeciones podría servir de apoyo a sus intereses estéticos. Arremetía contra la que él consideraba inconsistencia documental del profesor proclamando la revolución que había supuesto el pensamiento schopenhaueriano y el violento soplo de lógica con que había deshecho el edificio abstruso y mecánico de las quimeras de Hegel. Sobre todo irritaba al joven escritor asturiano que Bonilla hubiese hecho depender el simbolismo del idealismo romántico de Schopenhauer:

Ni los simbolistas son idealistas y románticos en cuanto simbolistas aunque lo pueden ser (Verhaeren, René Ghil, Stuart Merrill, etc. lo son) ni por serlo tienden a la doctrina, al sentido de los dos célebres filósofos del pesimismo. Estoy por asegurarle al Sr. Bonilla, que casi ninguno de los modernos poetas simbolistas ha leído a Schopenhauer ni muchísimo menos a Hartmann.

Un Pérez de Ayala, seguramente exasperado por la intromisión de la erudición académica en el terreno de la libre creación, cortaba por lo sano y trataba de restar razón a Bonilla, rebajándolo a la altura de la vulgarizada opinión que tenía a Schopenhauer como precedente del simbolismo decadente, pese a no ser santo de la devoción de Verlaine (Barre, 1912, pp. 108 y 163). Como es sabido, para el filósofo alemán, el artista no copia la realidad, sino que deduce de ella la Idea. El simbolista asedia la Idea, renuncia a su aprehensión absoluta, y sólo aspira a ofrecer una aproximación sugestiva, intuitiva, a la misma por medio de imágenes. Por ello Nordau identificaba a los simbolistas como degenerados y débiles de espíritu por su fuerte emotividad, su pensamiento confuso e incoherente, acusándoles de

23 También Martínez Ruiz y Pío Baroja habían mostrado abierta desconfianza ante el simbolismo como modelo literario, aunque en la práctica, no escaparan a sus efectos. Es interesante recordar que el primero, en una Crónica de El País (22-1-1897) se mostraba exasperado por no poder asumirlo plenamente a causa de su oscuridad: "No niego que en algunos de esos literatos simbolistas haya algo de revolucionario, y lo hay; pero ¿por qué escribir en esa forma obscura? ¿Por qué obstinarse en hacer incomprensible lo que puede ser claro como la luz". Por su parte, Baroja desconfiaba con más socarronería de los excesos simbolistas que incluye, entre los ejemplos de esnobismo modernista a la moda, en "Figurines literarios" (El País, 24-4-1 899). Cono Bonilla, también Baroja opinaba que los simbolistas se quedaban en las palabras y se limitaban a coleccionar palabras bonitas queriendo convencer de que expresaban mucho, aunque en úlimo término lo mismo les daba decir una idea que no decir nada. 
encubrir su desprecio por el saber positivo con fragmentos de ideas, frases incomprensibles audazmente mutiladas y de no tener como dignos del hombre más que $\mathrm{cl}$ sueño y la adivinación, "la intuición" en una palabra, que les hacía buscar la sombra de Schopenhauer (Nordau 1894, I, 180-181), cuyo rechazo de la simultaneidad de sensaciones y la ruina de la música como arte metafísico provocada por la gran ópera, observaba Nordau que no había sido correctamente interpretada por sus devotos, en especial por Richard Wagner y su decadente idea del drama musical, condenado como obra de arte universal del porvenir (Nordau 1894, I, 310-311). Blasco Ibáñez, wagneriano impenitente, se adhería a esta interpretación cuando, al caricaturizar el radicalismo estético de Isidoro Maltrana en La horda, ponía en su boca un grito de estirpe schopenhaueriana: "iViva la música! ¡Abajo la ópera!" (Blasco [1905] 1925, pág. 22).

\section{Tristeza y pesimismo}

Zozaya (1889, II, pág. 182) había distinguido con penetrante finura entre tristeza y pesimismo. La primera consistía en "aquella atmósfera mística y transparente de que se rodea la pena para aislarse en medio de la alegría y del ruido del mundo, a través de la cual penetran las irradiaciones armónicas de la Naturaleza". El pesimismo, por el contrario "envuelto en una atmósfera densa y compacta, impide que lleguen a nosotros aquellas irradiaciones, y lo que vemos en el fondo de nuestro ser lo trasladamos afuera, muriendo así la realidad toda en una sombría y negra obscuridad." El razonamiento viene a reforzar las inteligentes observaciones de Ángel L. Prieto de Paula (1991, págs. 76-77) cuando observa la análoga conversión de la "desesperación leopardiana" en "desesperanza modernista", marcada por su aceptación resignada de su inadecuación con el mundo. Así la tristeza (menos radical que el pesimismo, pero más fértil para la vida artística) viene a ser una especie de simulación convencional que los poetas de todos los tiempos han utilizado a discreción para alentar secretamente su propia vitalidad.

No obstante, incluso en el positivismo de Zozaya parece entreverse cierta receptividad simbolista, lo que, de ser cierto, enriquecería los indicios anticipadores de la aclimatación española de dicho movimiento hacia 1889. No hiló tan fino como Zozaya el propio Nordau, con toda su repercusión europea, al limitarse a definir el pesimismo como una de las formas filosóficas del egotismo, llegando incluso a meterlo en el mismo saco del naturalismo ${ }^{24}$. Para él, todas las objeciones de los filósofos pesimistas contra la naturaleza y la vida carecían de sentido, salvo que su premisa fuese el derecho a la soberanía del hombre sobre el cosmos.

24 "El pesimismo se encarnó casi al mismo tiempo en Italia y en Francia, en Leopardi y en Nicolás Lenau, más de una generación antes de que el naturalismo francés edificara su arte sobre él." (Nordau, 1894, II, pág. 472.) 
En este punto, por lo que sugiere el título y por su declaración de intenciones, no me resisto a aludir a La tristeza errante (1903) del madrileño Wenceslao Emilio Retana (nacido en 1862) - incluido en el canon de doña Emilia por esta única obra literaria en medio de una extensísima producción bibliográfica filipinista. Se trata de un texto sin novedades de estilo, construido con predominio de la omnisciencia narrativa, rota en el último capítulo por recursos epistolares y documentarios (fragmentarias noticias de prensa). Podría encuadrarse en el subgénero de novela social entendida como sátira de la aristocracia, decadente y corrupta, que cultivaron por aquellos años el P. Luis Coloma, Gutiérrez Gamero o Fernando Antón del Olmet ${ }^{25}$. Su pesimismo se inserta más bien en el simbolismo conceptual y unívoco, que expresa gradualmente las fases del conocimiento amoroso como un proceso que evoluciona aceleradamente hacia su agotamiento. Por ello la novela se divide en seis partes, tituladas: I, Curiosidad. II, Amistad. III, Deseo. IV, Pasión. V, Escepticismo. VI, Olvido. Tal estructura implica una tesis más próxima al concepto realista, que a la brumosa concepción modernista, por más que la cadena de enfermedades, dolor y desamor que afectan a la protagonista - la americana Lucinda Bowring - se resuelva con su suicidio en las tranquilas aguas del lago de Panticosa, lugar donde antaño había sido feliz. El autor, sin embargo, proclamándose mílite de la gente nueva ${ }^{26}$, declaraba irónicamente su inconformismo en un prólogo apócrifo, en forma epistolar, firmado por una tal Filomena, supuesta Marquesa de Cotollano, personaje de la novela y coleccionista de relatos eróticos, que sintetizaba los tópicos más corrientes del gusto reaccionario, ironizando sobre el "pesimismo revolucionario" - es decir, activo- de Retana, con amalgama explícita de Schopenhauer y el naturalismo, de lo científico y lo modernista:

Mal avenido con la vida práctica, sectario de Zola y otros indecentes como Zola, tiene usted la complacencia de presentar lo malo, y esto podrä ser cientifico y modernista, pero no es equitativo.

Usted es un triste habitual, porque en lugar de abrevarse en los autores divertidos, se abreva usted en Zola, en Tolstoi, en Mirbeau y en otros del mismo jaez; porque en lugar de embriagarse leyendo al bendito y sapientísimo Ortí y Lara, se embriaga usted leyendo al condenado e ignorante Schopenhauer. ¡Así está usted!...[...]

25. José Ferrándiz (Un Clérigo de esta Corte) al hacerse eco de este libro en El País (26-6-1903, pág. 2) observaba que "frente a las sociedades robustas, siquiera un tanto brutales, que ha creado el ideal moderno de protesta", el autor exponía "la turbamulta de idiotas, de bribones hipócritas, de estetas, de cornudos, de sáficas, de cursis, impotentes chocarreros, y en una palabra degenerados que llenan el balneario de Panticosa. ¡Bien elegido teatro! representando allí la Sociedad que ha creado la restauración y pulimentado la regencia, la sociedad tísica y llena de lepra jesuita, de virus frailuno".

26 Pese a su condición de cuarentón, a haber sido gobernador civil y a dedicar su libro al cacique oscense castelarino Manuel Camo, elevado a "modelo de políticos honrados", el mismo personaje contra quien Queral y Formigales había urdido cinco años antes su novela regeneracionista La Ley del embudo (1897). 
El sombrío pesimismo que corre por las páginas de La tristeza errante no recibe otros rayos luminosos que los revolucionarios, en todos los órdenes. Yo no sé qué mosca les ha picado a ustedes los liberales jóvenes de ahora, que se vanaglorian alardeando de anarquistas filosóficos. Pase que lo sean Picón, Blasco Ibáñez, Dicenta, Cavia, Castrovido, Dionisio Pérez, Morote y otros de esta calaña $[\ldots]$ En el caso que usted, aunque con mucho más talento que usted, están los Burell, los Figueroas, Maeztu, Canals, Francos Rodríguez, Pío Baroja, etc. ¡Qué lástima de juventud! Por supuesto; que ya les llegará a cada uno de ustedes la hora de la palinodia, como a Eusebio Blasco, que después de tanto cacarear su socialismo, su anticlericalismo, su ansia de revolución y demás zarandajas, ibuen cuidado tuvo de confesarse y abrazarse a la Virgen del Pilar a la hora de su muerte! (Retana 1903, págs. X, XVIII-XIX)27.

\section{La voluntad de vivir en Vicente Blasco Ibáñez o una hora de debilidad en la vida de un hombre de acción}

Escribir una novela como La voluntad de vivir en las primeras semanas de 1907 significaba para Blasco Ibáñez un ilusorio ajuste de cuentas con sus propios sentimientos heridos por una ruptura temporal con Elena Ortúzar, que creyó defïnitiva. Escribir esta novela y regresar a la política, de la que se había apartado el año anterior, eran hechos que respondían a un impulso común de sobreponerse a un período de debilidad en su agitada biografía política y literaria. Pero, ambas cosas se convierten en un espejismo, cuando a fines de abril de 1907 es derrotado electoralmente por Rodrigo Soriano y se reconcilia con su amante chilena. La consecuencia inmediata de este último hecho fue el repudio de la novela y la destrucción de los doce mil ejemplares que acababa de imprimir Francisco Sempere, para borrar los rasgos autobiográficos que pudieran dañar la imagen de la amada. $L a$ voluntad de vivir no llegó al público hasta junio de $1953^{28}$.

Bajo tal título parece razonable sospechar una vulgarización de las doctrinas de Schopenhauer. Y en cierto modo, el fracaso del científico Valdivia expresa la correlación schopenhaueriana entre dolor y conocimiento. Para Blasco el conocimiento sería el objeto más gratificante de la voluntad de vivir, mientras que el dolor estaría provocado por los sentimientos. Su alter ego, el maduro doctor que cifra en su curiosidad científica su "voluntad de vivir", es destruido por el ciego impulso amoroso, que obra a modo de genio de la especie frustrado por la seducción de Lucha, mujer fatal y voluble en la que se concentra cierto grado de misoginia resentida. Nada de extraño tiene que Blasco recurra a Schopenhauer a la hora de componer la novela más personal de su obra anterior a $1914^{29}$, ni que busque el

27 De esta novela hubo una "edición definitiva" ( parecía apostatar del pesimismo) en Barcelona: Ramón Sopena, s.a. [después de 1910], 268 págs.

28 Sobre este episodio biográfico véase J. L. León Roca (1990, págs. 343-355).

29) Con anterioridad Blasco Ibáñez recurrió a Schopenhauer para reforzar su tesis anticlerical en el cap. III de La catedral [1903] 1909, pág. 82. 
sesgo más positivo de la voluntad de vivir, con tesis encubicrta que, lejos de desembocar en la aceptación de la nada absoluta, advierte, al modo naturalista, sobre el determinismo de la pasión (genio de la especie) y sus perniciosos efectos sobre la voluntad intelectualizada. La propia condición científica del protagonista y la capacidad de discernimiento que se le presupone denuncia a voces la referencia schopenhaueriana de que "cuanto más ilustrado, más el hombre sufre".

La voluntad de vivir no es una novela vigorosa, sin el empaque de cuadro mural que Blasco solía ofrecer a sus lectores, ni una novela doctrinal con incursiones metafísicas que no le iban, sino un estudio próximo al naturalismo psicológico que transfiguraba su estado de ánimo, herido por un amor que lo distraía de sus actividades públicas. Pero el autor, acostumbrado a explicar el mundo con suficiencia naturalista, no acertó a formalizar sus conflictos íntimos con una técnica introspectiva innovadora, renunciando a una excelente ocasión de provocar una inflexión en su lentísima evolución literaria. El relato se cimenta en una afirmación realista de la voluntad de vivir tras una rapida alusión a los tres estados de ilusión del "pesimista" Hartmann, "dulces mentiras inventadas por el micdo" ante las cuales Enrique Valdivia se muestra escéptico y contrapone una lógica mucho más negativa cuyo pragmatismo expresa la débil moral positivista, lejos de la tremenda lucidez metafísica de Schopenhauer. En el fondo, el discurso del novelista pasa implícitamente por el del filósofo en un intento de rectificar su doctrina, adaptándola a la lógica del realismo naturalista:

...hay que vivir. No debemos pasar la existencia en continuo terror, pensando a todas horas en algo que al fin es inevitable. Hay que tener la voluntad de vivir, $y$ yo la tengo. Debemos aceptar la vida como es y cifrar toda nuestra sabiduría en prolongarla el mayor tiempo posible. Yo no tengo "estados de ilusión" que me ayuden a sobrellevarla; apenas si el estudio y la gloria personal me sirven de apoyo para seguir adelante. Trabajo por costumbre y porque esto me distrae de la negra idea que a veces me barrena el pensamiento; pero amo la vida por sí misma, porque siento la necesidad de vivir, de conservar mi personalidad, porque el instinto me une a ella... porque lo que llaman sabiduría me ha hecho tener mayor miedo a la muerte. La vida es lo único cierto: hay que estirarla todo lo que se pueda (Blasco 1953, pág. 26).

Al final del primer capítulo el dolor de vivir se presenta como una paradoja vitalista. Valdivia se cruza con la muerte en dos planos sociales: primero, cl cortejo fúnebre empenachado y solemne, que avanzaba "con la calma altanera del prócer que llega tarde a todos los sitios"; después, el inevitable contraste: tres hombres "de paso inseguro" y "gorra caída sobre una oreja" uno de los cuales llevaba bajo el brazo "un pequeño ataúd blanco, última cuna de un niño".30:

30 Recuérdese el mismo motivo del entierro infantil, tratado con anterioridad por Martínez Ruiz y por Baroja, situado por ambos en Toledo (La voluntad y Canino de perfección, 1902). 
La vida es triste...-reflexiona el protagonista. Dolores, desilusiones, y la nada al final como resultado de tanta inquietud. Pero los hombres pasan junto a la muerte sin fijarse en ella, y aunque no sabemos por qué estamos aquí ni a qué conduce nuestra vida, la humanidad grita rabiosamente: "QQuiero vivir", y este deseo la engaña y la sostiene. La vida a toda costa, sea como sea; por el placer de vivirla, por el gusto de existir, por la satisfacción de haber nacido (Blasco 1957, p. 37).

Pero la emoción -excitación nerviosa, búsqueda del estremecimiento exterior- irrumpe en la vida anodina del científico. La emoción es una trampa del instinto, que aparenta completar el conocimiento. Valdivia cede al atractivo femenino de su amada Lucha como una concesión al genio de la especie. Su viaje a París en pos de la enigmática sudamericana se justifica como una afirmación de la voluntad: "marchar al encuentro de la alegría y el amor que fortalecen la voluntad de vivir". Ésta consiste en evitar el dolor, instalarse en la felicidad: si hay que morir, que sea de amor, "morir en plena felicidad" es la propuesta romántica de Lucha (Blasco 1953, pág. 162). La rememoración del suicidio de Sara, su primera amante enturbia la memoria de Valdivia y aparece como motivo recurrente que, en la mejor línea schopenhaueriana, se presenta como supresión del dolor y disolución en la nada: "Sentía la admiración del débil ante aquel coraje fiero que, pisotcando el más poderoso de los instintos, llegaba a la supresión de la existencia" (id., págs. 175 y 210). Valdivia siente miedo ante los grandes dolores humanos, que él no había sufrido nunca. Y por fin, llega la indeseable experiencia como privación del amor, que conduce a la destrucción del personaje, minúscula partícula de la cadena filogenética (id. pág. 276) incapaz ya de superar la trágica contradicción entre pasión instintiva y voluntad de vivir en el plano del conocimiento:

¿Quién era él, próximo a la vejez y sin otro atractivo que el prestigio de su nombre, para encadenar a su decadencia una juventud ansiosa de curiosidades? Era un empeño de sobrevivirse, de querer trastornar el curso de la duración de las estaciones de la vida. Llegaba el invierno. ¡A casa...! Horas antes, a impulsos de la cólera, había recordado varios problemas de investigación que le apasionaban cuando aún no conocía a Lucha. Volvería a ellos; dedicaría el resto de su existencia al trabajo. Tendría un amor, el antiguo, el que le hacía sufrir algunas veces, pero no le engañaba nunca: el amor al estudio. Se entregaría otra vez al egoismo de prolongar su existencia: sentiría la voluntad de vivir, olvidada en los últimos tiempos.

"Trabajar para vivir", se decía animándose internamente con estas palabras. Pero en su pensamiento se rebelaba algo contra lo incompleto de tal propósito, añadiendo con sorda terquedad: "Y vivir para amar" (id., págs. 45-46).

A la voluntad de vivir se opone la inevitabilidad del dolor en una aparente correlación con el planteamiento del filósofo alemán - "querer es esencialmente sufrir, y como vivir es querer, toda vida es esencialmente dolor"-, pero el novelista valenciano en una ambigua pirueta concluye su relato dejando morir al protagonista y abriendo una vía espiritualista, sorprendente por lo inesperada en un escritor radical, con el arrepentimiento de Lucha -detonante de la catástrofe-que 
busca consuelo a su mala conciencia en la catedral de Nôtre Dame entre los espas mos de una religiosidad compulsiva.

A lo largo de estas notas, sin salir de las formulaciones hipotéticas, hemos observado tres tendencias en la recepción - implícita o explícita- del pesimismo filosófico entre escritores españoles alrededor de 1900: a) resistencia (Antonio Zozaya y otros positivistas o regeneracionistas); b) aceptación o abierta identificación (Baroja, Martínez Ruiz, Pérez de Ayala, etc., coincidiendo con la consolidación del simbolismo modernista), y c) manipulación (Blasco Ibáñez).

Pero maticemos: quizá, salvo en el caso de Baroja, llevado a sus consecuencias extremas tardíamente en El árbol de la ciencia (1911), la recepción finisecular de Schopenhauer se decantó en el sentido que Adalbert Hämel atribuyó al propio débito que el filósofo alemán había contraído con la literatura clásica española. En Cervantes, Calderón o Gracián,

halló el pesimismo en cuanto al mundo, a la vida y a los hombres; halló la abnegación en cuanto a las cosas terrenas; halló el ardiente deseo de salvarse del mal del mundo; halló todos los pensamientos de la Edad Media metafísica dentro de los autores españoles del tiempo del Barroco.

Pero este pesimismo empírico del pensamiento español difiere del pesimismo de Schopenhauer en que no se contenta con la negación y, aunque mira el triunfo del dolor sobre la alegría dentro de los límites de la fugacidad temporal, se orienta finalmente hacia un optimismo que procede de una convicción religiosa que le preservó siempre de hundirse en el nirvana y de creer que la muerte es el fin de todo (Hämel, 1926, págs. 45-46).

Pues bien, la generación de 1868, aunque laica, coincidía con esta actitud tradicional española consistente en extraer doctrina positiva del pesimismo. Por tanto el pensamiento del filósofo alemán no podía producir simpatía entre ellos, a no ser por lo que tenía de afirmación vitalista del genio de la especie (como apuntaba Max Nordau).

Si Schopenhauer había bebido en la literatura española del desengaño barroco el licor más adecuado a su negativa visión de la vida, tras asimilarlo, sólo podía devolverlo acrecentado a la primera generación literaria española que pudo mostrársele receptiva, la que, entre dos siglos, vivió exasperadamente la disolución del positivismo y se reconoció en la negación metafísica del filósofo alemán. En ella, por un lado, su pensamiento fue interpretado en todo su desolador contenido (Baroja especialmente) y por otro, persistió la actitud tradicional, aunque tratando 
de buscar un moderno sentido vitalista al pesimismo, liberado del sentido religioso. Tradición pesimista que constataba en tono severo Ramiro de Maeztu (1900)nada schopenhaueriano, por cierto- al juzgar otro olvidado libro en la órbita de ía literatura melancólica, La tristeza de vivir, de F. Pérez Mateos (León Roch):

Ve usted la miseria bajo las chisteras y los zapatos de charol; la soledad y la fatiga ocultas en la nombradía aparatosa de los escritores y de los artistas; enfoca usted la visión hacia las vidas fracasadas; se complace describiendo desde cerca la fealdad horripilante de los bastidores.

Por el fondo, por la forma y por las proporciones de sus escritos, es usted genuinamente español. Esa propensión a describir seres frustrados, caracteriza a nuestra literatura. Ni aun imaginativamente comprendemos el héroe. Brandi y Zarathustra han tenido que ser engendrados bajo otros cielos. Nuestros personajes no logran nunca remontarse por encima de los tejados; de ser pájaros Don Quijote, Don Juan y Orozco tendrían las alas rotas.

En todo caso, predomina la impresión de que, hacia 1900, este activo pesimismo de la literatura española, estimulado circunstancialmente por la lectura de Schopenhauer, tenía raíces y motivaciones propias en una tradición, más o menos sostenida, que va desde los místicos y Calderón a Bécquer.

\section{OBRAS CITADAS}

ALONSO, Cecilio. 1995. "Una carta abierta de Antonio Machado a D. Miguel de Unamuno, 1903”, Ínsula, 580, pág. 8.

ARA TORRALBA, Juan Carlos. 1990. "El alma contemporánea de Alma Contemporánea, claves ideológicas para un libro y un cambio de siglo", Alazet, 2, págs. 9-54.

BAROJA, Pío. [1896] 1973. El dolor. (Estudio de psico-física); en Hojas sueltas, II; ed. de Luis Urrutia Salaverri, Madrid, Caro Raggio, 1973.

— 1899. "Nietzsche y su filosofía”, Revista Nueva, 1, 15-2-1899, págs. 21-27

— [1900] 1948. Vidas sombrías; en OC, VI. Madrid, Biblioteca Nueva.

— [1917] 1977. Juventud, egolatría; pról. de Julio Caro Baroja, Madrid, Taurus.

- [1920] 1948. La sensualidad pervertida, en OC, II. Madrid, Biblioteca Nueva.

- 1944. Desde la última vuelta del camino. Memorias. El escritor según él y según los críticos, Madrid, Biblioteca Nueva.

- [1944a] 1951. Desde la última vuelta del camino. Memorias. Familia, infancia y juventud; $2^{\mathbf{a}}$ ed., Madrid, Biblioteca Nueva. 
- 1945. Desde la última vuelta del camino. Final del siglo XIX y principios del XX. Madrid, Biblioteca Nueva.

- 1948a. Desde la última vuelta del camino. Memorias. La intuición y el estilo, Madrid, Biblioteca Nueva.

- 1972. Escritos de juventud (1890-1904); ed. de Manuel Longares, Madrid, Edicusa.

BARRE, André. 1912. Le symbolisme. Essai historique sur le mouvement poétique en France de 1885 a 1900, Paris, 1912, 2 t. [Reimpresión: Genève-Paris, Slatkine, 1993]

BLASCO IBÁÑEZ, Vicente. [1903] 1909. La Catedral. Novela, Valencia, F. Sempere. - [1905] 1925. La horda. (Novela), Valencia, Prometeo.

- 1953. La voluntad de vivir. Novela póstuma, Barcelona, Planeta, 1953. 377 págs..

BONILLA Y SAN MARTÍN, Adolfo. 1902. El Arte simbólico. Esbozo de una teoría de las formas artísticas, Madrid, Est. Tip. Viuda e hijos de Tello, 1902.

BROTO SALANOVA, Justo. 1992. Un olvidado: José $M^{a}$ Llanas Aguilaniedo, Huesca, Instituto de Estudios Altoaragoneses.

CALVO CARILLA, José Luis. 1990. "Alma contemporánea; una estética de la modernidad", Castilla, 15, págs. 33-51.

CANSINOS ASSENS, Rafael. 1925. La nueva literatura. II. Las escuelas. 1898. 1900-1918; $2^{a}$ ed. Madrid, Páez.

CARO, Érasme. 1893. El pesimismo en el siglo XIX. Leopardi.-SchopenhauerHartmann, Madrid, La España Moderna, s.a.

(CLARÍN), ALAS, Leopoldo. 1892. Ensayos y revistas. 1888-1892, Madrid, M. Fernández y Lasanta.

CORREA RAMÓN, Amelina. 1996. Isaac Muñoz (1881-1925). Recuperación de un escritor finisecular, Granada, Universidad.

DAVIS, Lisa E. 1977. "Max Nordau, Degeneración y la decadencia de España", Cuadernos Hispanoamericanos, 326-327.

DELEITO Y PIÑUELA, José. 1922. El sentimiento de tristeza en la literatura contemporánea, Barcelona, Minerva.

DEMUTH, Helmut. 1937. Pio Baroja. Das Weltbild in seine werken, Hagen.

GENER, Pompeyo. 1894. Literaturas malsanas. Estudios de patología literaria contemporánea, Gerona, Imp. de Paciano Torres. 
GINER DE LOS RIOS, Francisco. [1869] 1922. "El alma de los animales"; en Estudios filosóficos y religiosos, Madrid: Espasa-Calpe.

— [1872] 1919. "Qué es lo cómico"; en Estudios de Literatura y Arte, Madrid: La Lectura.

GONZÁLEZ SERRANO, Urbano. 1902. "El modernismo", El Mercantil Valenciano, 8-7-1902.

GULLÓN, Germán. 1992. La novela moderna en España (1885-1902). Los albores de la modernidad, Madrid, Taurus, págs. 97-99.

HÄMEL Adalbert. 1926. "Arturo Schopenhauer y la literatura española"; en Conferencias y trabajos [...] durante el curso de 1924-1925, Universidad de Madrid.

HUELIN, Emilio. 1870. “Congresos de filósofos en Alemania”, Boletín-Revista de la Universidad de Madrid, II, 11, (10-3-1870), págs. 665-683.

LEÓN ROCA, José Luis. 1990. Vicente Blasco lbânez; $4^{\mathrm{a}}$ ed., Valencia.

LLANAS AGUILANIEDO, José Mª [1900] 1991. Alma contemporánea. Estudio de estética; ed. Justo Broto Salanova, Huesca, Instituto de Estudios Altoaragoneses, 1991.

- 1902. Del jardín del amor Novela, Madrid, F. Fe-V. Suárez.

KRAUSE, Anna. 1955. Azorín, el pequeño filósofo. Indagaciones en el origen de una personalidad literaria, Madrid, Espasa-Calpe.

MACÍAS PICAVEA, Ricardo. 1897. La Tierra de Campos, Madrid, V. Suárez, 1897.

MACHADO, Antonio. 1936. Juan de Mairena. Sentencias, donaires, apuntes y recuerdos de un profesor anónimo, Madrid, Espasa-Calpe.

- 1957. "Leibniz y Schopenhauer"; en Los complementarios y otras prosas póstumas; ed. de Guillermo de Torre, Buenos Aires, Losada, 1957.

MAEZTU, Ramiro de. 1900. "La tristeza de vivir", El País, 30-11-1900, pág. 3.

MAINER, José Carlos. 1989. "La crisis de fin de siglo a la luz del "emotivismo": sobre Alma contemporánea (1899), de Llanas Aguilaniedo"; en Letras aragonesas (siglos XIX y XX, Zaragoza: Oroel, págs. 97-115.

MARTÍNEZ RUIZ, José. 1894. "Los anarquistas (Notas de un libro ajeno)", El Mercantil Valenciano, 18-4-1894.

- 1895. "Las ilusiones perdidas", El Pueblo, Valencia, 6-5-1895.

- 1899. La sociología criminal, Madrid, F. Fe. 
MOREL-FATIO, A. 1910. "Gracián interpreté par Schopenhauer", Bulletin Hispanique, XII, págs. 337-407.

MUÑOZ LLORENTE, Isaac. 1904. Vida, Granada, Imp. Paulino V. Traveset.

NORDAU. Max. 1894. Dégénérescence; trad. de Auguste Dietrich, Paris, Félix Alcan, II, 353-354.

PARDO BAZÁN, Emilia. 1904. "La nueva generación de novelistas y cuentistas en España", Helios, II, XII, págs. 257-270.

PÉREZ DE AYALA, Ramón. 1903. "Los libros. El arte simbólico, estudio de una teoría de las formas artísticas, por Adolfo Bonilla y San Martín", El País, 4-21903.

PÉREZ GALDÓS, Benito (1876), "Doña Perfecta", Revista de España, XLIX, págs. 231-268 y 374-415.

- 1887. Fortunata y Jacinta (Dos historias de casadas), Madrid, La Guirnalda.

— 1890. Realidad. Novela en cinco jornadas. Madrid, La Guirnalda.

PRIETO DE PAULA, Ángel Luis. 1991. “Desde Leopardi a los escritores españoles de fin de siglo: hacia una caracterización del "mal de la tierra", Quaderni di Filologia e Lingue Romanze, $3^{\mathrm{a}}$ serie, 6, págs. 65-80.

RETANA, Wenceslao E. 1903. La tristeza errante. Novela, Madrid, F. Fe, 1903, 386 págs.

SCHOPENHAUER, Arturo. [1851] 1889. Parerga y paralipomena. Aforismos sobre la sabiduría de la vida; trad. de Antonio Zozaya, Madrid, Biblioteca Económica Filosófica, 2 t.

- [1818-1844] 1960. El mundo como voluntad y representación; trad. de Eduardo Ovejero y Mauri; $2^{\mathrm{a}}$ ed., Buenos Aires, Aguilar, 1960, 3 t.

- 1904. Los dolores del mundo, Barcelona, Presa.

SOBEJANO, Gonzalo. 1967. Nietzsche en España, Madrid, Gredos.

TRIVIÑO, Consuelo. (1995). “Pompeu Gener y el Modernismo”, Quimera, 138, págs. 46-50.

UNAMUNO, Miguel de. 1902. Amor y pedagogía, Barcelona, Henrich y cía.

ZOZAYA, Antonio. 1889. "Epílogo"; en SCHOPENHAUER, Arturo, Parerga y paralipomena. Aforismos sobre la sabiduria de la vida; trad. de Antonio Zozaya, Madrid, Biblioteca Económica Filosófica, 2 t. 